RUMBA RULES 


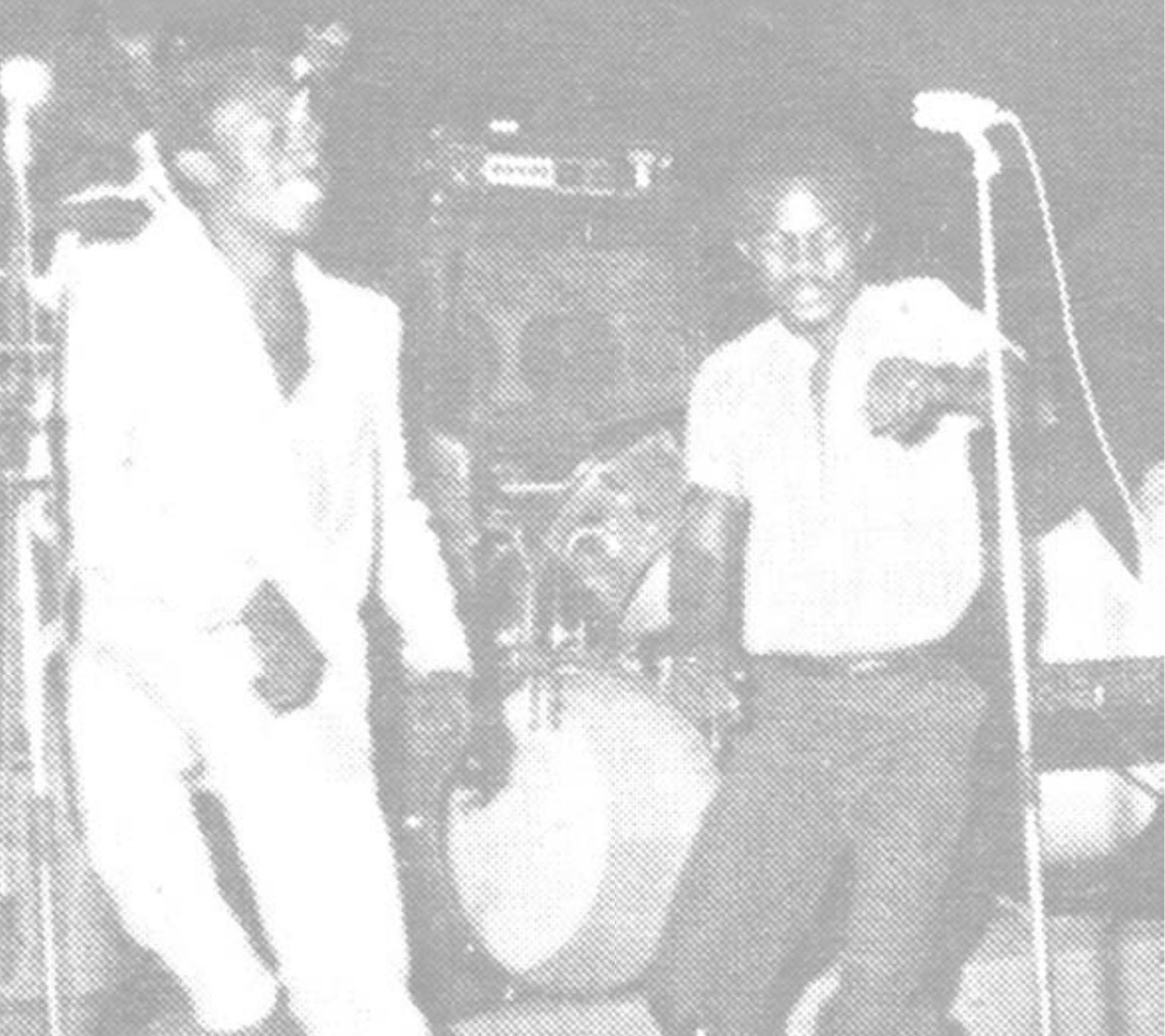




\section{RUMBA RULES}

The Politics of Dance Music in Mobutu's Zaire

\section{Bob W. White}

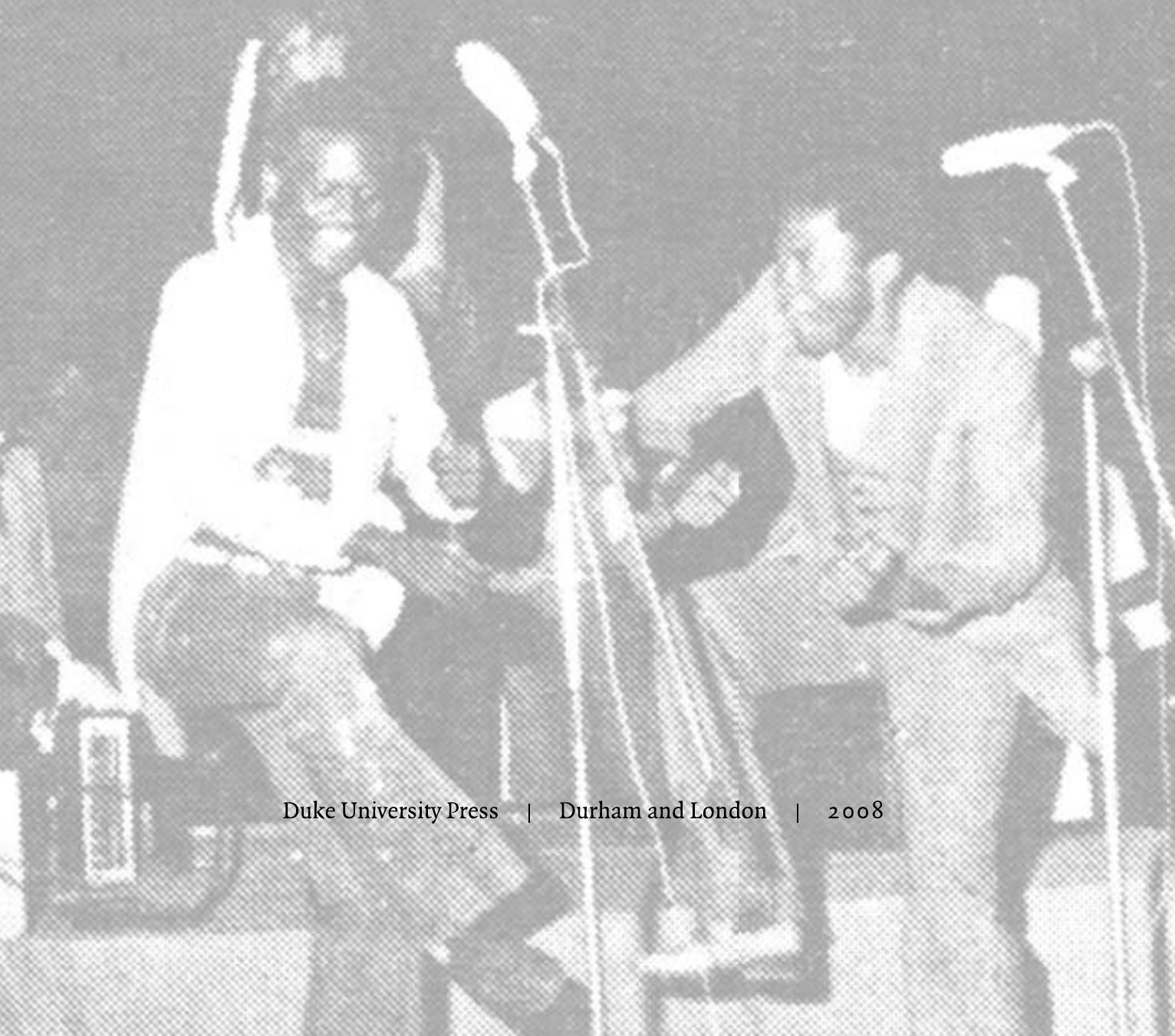




\section{() 2008 Duke University Press}

All rights reserved.

Printed in the United States of America on acid-free paper $®$

Designed by Heather Hensley

Typeset in Quadratt by Tseng Information Systems, Inc.

Library of Congress Cataloging-in-Publication Data appear

on the last printed page of this book. 
To Lucie, Jeremy, Aria, and Piccolo 

Since he has taken us by the hand, let him not forget about us! Let him make it possible for us to play music! That will enable us to take care of ourselves, instead of him using all his energy to take care of us. Let him always think of us, because sometimes we forget to finish what we started! Let us continue to sing and live in the best of conditions! We live for music. Let our music find a place in the history of Zaire for the generations of our children and our grandchildren! We will be unified to be strong and to defend the rights of our ancestors, just as we seek friendship with others who are sincere.

“MESSAGE FROM ARTISTS TO PRESIDENT MOBUTU SESE SEKO," 1974

À travers la vision du monde de l'artiste, un spécialiste du beau, du sublime, de la jouissance, est offerte une perspective esthétique sur l'expérience et sur le savoir.

BOGUMIL JEWSIEWICKI 
